\title{
Castor Bean Cake Protein-based Biodegradable Films: Gallic Acid Effect
}

\author{
Hulda Noemi Chambi Mamani ${ }^{1}$ \\ https://orcid.org/0000-0001-8421-4695 \\ Juliana Augusti Graziano ${ }^{2}$ \\ https://orcid.org/0000-0001-9993-2673

\section{Roseli Sengling Lacerda ${ }^{2}$} \\ https://orcid.org/0000-0003-3218-4767
}

Ana Mônica Quinta Barbosa Bittante
https://orcid.org/0000-0002-0381-8399

\section{Catarina Abdalla Gomide ${ }^{2}$}

https://orcid.org/0000-0001-6414-1927

\section{Paulo José do Amaral Sobral ${ }^{\star}$}

https://orcid.org/0000-0002-3913-3172

\section{${ }^{1}$ State University of Campinas, Faculty of Food Engineering, Campinas, São Paulo, Brazil; ${ }^{2}$ University of São Paulo,} Faculty of Animal Science and Food Engineering, Pirassununga, São Paulo, Brazil.

Received: 2019.03.10; Accepted: 2020.02.07.

${ }^{*}$ Correspondence: pjsobral@usp.br; Tel.: +55-19-35656857 (P.J.A.S.)

\section{HIGHLIGHTS}

- The proteins modification by gallic acid (GA) keeps films dark and opaque.

- Films solubility, tensile strength and elasticity modulus were dependent on the GA.

- The gallic acid stabilize interactions between proteins by non-covalent bonds.

- The films based on castor bean cake proteins modified by gallic acid are biodegradable.

Abstract: The objective of this work was to evaluate the effect of gallic acid (GA) concentration on some physical properties and biodegradability of films produced with proteins extracted from the castor bean cake. The films, prepared by the casting technique, showed homogeneous and brownish appearance. As the GA concentration increased (from 0 to $10 \mathrm{~g} / 100 \mathrm{~g}$ protein), the films gradually became darker and more opaque; while the gloss had few significant differences. Solubility, tensile strength and elasticity modulus values of films varied due to changing concentrations of gallic acid. Elongation at break and water vapor permeability values did not have significant changes. A $60 \%$ mineralization value of the film containing GA was obtained at 21 days, evidencing its biodegradability. These dark and opaque films could be used in agriculture, specifically in seedling bags as the dark color decrease the incidence of light, preventing root weakening, and the seedlings can be transplanted directly without removal of the film.

Keywords: Ricinus communis L.; physical properties; biodegradability; seedling bags 


\section{INTRODUCTION}

The development of biodegradable films is part of attempts to overcome environmental problems caused by the accumulation of non-biodegradable synthetic packaging. In agriculture, films are used in the manufacture of greenhouses, low tunnels, soil cover, seedling bags, waterproofing of reservoirs and irrigation canals, among others. In the production of seedlings, the biodegradable films can be a good alternative in the improvement of the management, since the seedlings can be transplanted directly without removal of the packaging.

Biodegradable films can be produced from proteins, polysaccharides and lipids obtained from a variety of crop sources, especially from waste streams produced by the agro food industry [1]. Proteins are heteropolymers composed of many amino acids linked together through peptide bonds and with strong intermolecular interactions by sulfhydryl bonds, hydrogen bonds and van der Waals forces. This unique structure confers to proteins a wide range of functional properties, including significant intermolecular binding potential allowing protein-based films to exceed mechanical properties of polysaccharide and lipid-based films [1-3]. The proteins-based films have physical properties which could be considered as restrictive to practical applications. Some strategies for improving the physical and/or functional properties of these materials involve enzymatic, physical or chemical treatments of proteins [2,3].

Castor plant is an important non-edible oilseed crop used for biodiesel production. The castor bean cake, produced during oil extraction in Brazilian industries, contains approximately $40 \%$ of proteins; whereas the freeze-dried protein extracted by dispersing milled cake in alkaline medium contains $66-69 \%$ [4-7]. The valorization of these proteins aims to contribute with the biodiesel production chain. The proteins extracted from castor bean cake showed good filmogenic properties, allowing the production of films with good plasticity and elasticity $[5,6,8]$. Films have been produced with proteins extracted at different pHs, different concentrations, with the addition of tannic acid [5], glutaraldehyde and glyoxal [6] and cellulose fibers [8]. The films produced with the proteins extracted at $\mathrm{pH} 12$ had a more cohesive structure, lower water vapor permeability, high elongation at break and lower hydrophilicity when compared to films produced with proteins extracted at $\mathrm{pH} 10$ or 11 [5]. The films produced with proteins modified with glyoxal presented the best mechanical properties and the less solubility in relation to the films made with proteins modified with glutaraldehyde [6]. The mechanical properties of the films produced with glyoxal-modified proteins can be improved with the addition of cellulose fibers [8].

Gallic acid is the main structural unit of tannins, is a non-toxic vegetable product, and has an excellent protein-modifying capacity, and not yet used in castor cake protein film technology. Gallic acid has been used in the modification of proteins extracted from sunflower cake for film production [9]. These films had lower solubility and higher tensile strength and elongation at break when compared to the films produced with the same proteins modified with tara and chestnut tannins [9]. Films of zein and chitosan prepared with gallic acid had antimicrobial and antioxidant activity [10-12]. Gallic acid acts through hydrogen and hydrophobic interactions rather than covalent bonds as in the case of aldehydes [9,13]. The interactions stabilizing the protein network can be weakened at concentrations of gallic acid above optimum, damaging the film's coherence [9].

The objective of this work was to evaluate the effect of gallic acid (GA) concentration on some physical properties and biodegradability of films produced with proteins extracted from the castor bean cake.

\section{MATERIAL AND METHODS}

\section{Film production}

The films were produced with proteins extracted from castor bean cake, obtained by donation (A. Azevedo Ind. Com. Oils Ltd., Itupeva, SP, Brazil). The protein extraction was performed by solubilization in alkaline medium $(\mathrm{pH}=12)[5]$. The protein content and amino acid profile were determined previously and the results were published elsewhere [6,7,14].

The films were produced by casting technique at room temperature $\left(22-25^{\circ} \mathrm{C}\right)$ [5]. The freeze-dried protein $(7 \mathrm{~g} / 100 \mathrm{~g}$ solution) was slowly mixed with distilled water under continuous stirring for 30 minutes, to ensure complete dispersion. Then, gallic acid $(0,1,3,6$, and $10 \mathrm{~g} / 100 \mathrm{~g}$ of protein) purchased from SigmaAldrich (Munich, Germany), previously dispersed in ethanol ( $8 \%$, w/v) was added, and the mixture was maintained under stirring for more 30 minutes for allowing the reaction between the gallic acid and proteins. Finally, glycerol was added (30 g/100 g protein) and the mixture was kept stirring for more 5 minutes, thus obtaining a film-forming solution (FFS). No agent was added to control the $\mathrm{pH}$ of FFS, which was $11.0 \pm 0.3$ 
at the end of the FFS production process. FFS was spread onto $15 \mathrm{~cm}$ in diameter polystyrene plates and dried in an oven with forced air circulation at $30{ }^{\circ} \mathrm{C}$ for $15-18 \mathrm{~h}$. The films were stored in desiccators containing saturated solution of $\mathrm{Mg}\left(\mathrm{NO}_{3}\right) 2.6 \mathrm{H}_{2} \mathrm{O}$ at $23{ }^{\circ} \mathrm{C}$, at $54 \%$ relative humidity, for 5 days, prior to characterization. This film production process was repeated three times for each experiment.

\section{Film characterization}

\section{Film thickness and moisture content}

Film thickness was measured using a digital micrometer (MITUTOYO, Japan) with $0-25 \mathrm{~mm}$ range and $0.001 \mathrm{~mm}$ graduation. The final thickness was the average of ten measurements made randomly throughout each determination. Moisture content was determined by drying the film sample $(\sim 2 \mathrm{~g})$, at $105^{\circ} \mathrm{C}$, for 18 $24 \mathrm{~h}$. These results were expressed on a wet basis.

\section{Color, opacity and gloss}

Color, opacity, and gloss were measured on the top surface of the films, i.e. on the drying surface, using a colorimeter MiniScan XE - HunterLab (Hunterlab Associates Laboratory, Virginia, USA) controlled by the software program Universal 3.2 [15]. The films were placed on the surface of a standard white plate and the parameters $L^{*}, a^{*}$, and $b^{*}$ were measured using CIELab color scale. The color difference $\left(\Delta \mathrm{E}^{*}\right)$ was calculated using the standard black plate $\left(L_{s}{ }^{*}=0.02 ; a_{s}{ }^{*}=0.08 ; b_{s}{ }^{*}=0\right)$ according to the Equation 1 :

$$
\Delta E^{*}=\sqrt{\left(L^{*}-L_{s}^{*}\right)^{2}+\left(a^{*}-a_{s}^{*}\right)^{2}+\left(b^{*}-b_{S}^{*}\right)^{2}}
$$

Opacity was calculated directly using the program Universal Software 3.2, as the ratio of the opacity of the films overlapping the black pattern $(Y b)$ and the white standard $(Y w)$. For gloss determination [16,17], the Rhopoint NGL 20/60 glossmeter, at an angle of $60^{\circ}$, was used.

\section{Film solubility}

Film solubility was measured in water [18]. Films were cut into discs (2 cm in diameter), immersed in distilled water $(50 \mathrm{~mL})$, and kept under mechanical stirring (Marconi-MA 141 stirring table, SP, Brazil) for 24 $\mathrm{h}$ at room temperature $\left(22-23^{\circ} \mathrm{C}\right)$. After this period, samples were filtered through $80 \mathrm{~g} / \mathrm{m}^{2}$ and $3 \mu \mathrm{m}$ porosity filter paper (Nalgon, Itupeva, SP, Brazil). Filter paper containing the film without solubilization was dried $\left(105^{\circ} \mathrm{C}, 24 \mathrm{~h}\right)$ and weighed. The final dry mass was determined by discounting the weight of the filter paper. Initial dry mass was calculated knowing the initial moisture of the samples. Solubility was expressed in terms of dissolved dry mass.

\section{Mechanical properties}

The mechanical properties were determined by a tensile test using a texture analyzer TA.XT2i (TA Instruments, Godalming, UK), according to the American Standard Testing Method (ASTM) D882-95a [19]. The conditions of these tests were: film size $=15 \mathrm{~mm} \times 100 \mathrm{~mm}$; initial distance between the grips $=50 \mathrm{~mm}$ and crosshead speed $=0.9 \mathrm{~mm} / \mathrm{s}$. Values of tensile strength (TS) and elongation at break (EB) were obtained directly from the stress versus elongation curves, and the elasticity modulus was calculated from the slope of the linear region of the stress versus elongation curves, using the software of equipment (Exponent Lite Express v. 4.0).

\section{Biodegradability}

The biodegradability tests were performed only with films produced with $6 \mathrm{~g}$ gallic acid/100 $\mathrm{g}$ protein, using respirometric method NBR 14283 [20], which determines the aerobic biodegradability of residues in soil by measuring the amount of carbon dioxide released. The tests were carried out at the Sanitation Laboratory of the State University of Campinas (Unicamp, SP, Brazil) for 93 days. The soil used for the tests were collected at the Campus and presented the following characteristics: $33.7 \%$ clay, $14.1 \%$ silt, $52.9 \%$ sand, $1.23 \%$ organic matter, and $\mathrm{pH}=5$.

The films were finely cut with scissors and mixed with the soil, using an application rate of $0.38 \mathrm{~g}$ of film per $50 \mathrm{~g}$ of soil (20 Ton/hectare of soil). The film mixture plus soil was transferred to the respirometer and stored in BOD (Tecnal 390, SP, Brazil), under controlled temperature of $25^{\circ} \mathrm{C}$. The aeration system was 
performed with an aerator with a flow rate of $2.5 \mathrm{~L} / \mathrm{min}$ of air. During the experiment, soil moisture was maintained constant at $50 \%$ of its water retention capacity $(\approx 211 \mathrm{~g} / \mathrm{kg}$ of soil). The carbon dioxide released from the film biodegradation was determined by conductivity measurements for 93 days [21]. The biodegradability (B) of the films [22], expressed as a percentage, was calculated according the Equation 2:

$$
B=\frac{C_{f}-C_{c}}{C_{t}} \times 100
$$

Where $C_{f}$ is the amount of $\mathrm{CO}_{2}$ released in the respirometer containing the film, between the beginning of the test and the time $t(\mathrm{mg}) ; C_{c}$ is the amount of $\mathrm{CO}_{2}$ released in the control respirometer, between the beginning of the test and the time $t(\mathrm{mg}) ; C_{t}$ is the theoretical amount of $\mathrm{CO}_{2}$ in the film $(\mathrm{mg})$.

The theoretical amount of $\mathrm{CO}_{2}\left(C_{t}\right)$ produced by the films [22] was calculated according the Equation 3 :

$$
C_{t}=w \times x_{c} \times \frac{44}{12}
$$

Where $w$ is the mass of film $(\mathrm{mg})$ introduced into the respirometer; $x_{c}$ is the carbon content of the film (without gallic acid $=40.8 \%$, with gallic acid $=36.4 \%$ ) determined by elemental analysis and expressed as a mass fraction.

\section{Statistical analysis}

Data were analyzed by ANOVA and Tukey's multiple tests at $95 \%$ confidence level, using the statistical program "Statistical Analysis Systems" (SAS).

\section{RESULTS AND DISCUSSION}

\section{Film thickness and moisture content}

The thickness of the castor bean cake proteins (CBCP) films remained $(p>0.05)$ between 91 and 100 $\mu \mathrm{m}$ (Table 1). This result was probably due to the control of the dry mass of the film-forming solutions per support area, in addition to the modification of the protein by gallic acid, which did not affect the density of the protein matrix. The thickness of these films was greater than the thickness of low-density polyethylene films $(48 \pm 3 \mu \mathrm{m})$ usually used in the management of plant seedlings $[5,23]$.

Table 1. Thickness, moisture content, color, and gloss of films made with castor bean cake protein modified by gallic

\begin{tabular}{|c|c|c|c|c|c|c|}
\hline \multirow{2}{*}{$\begin{array}{c}\text { Gallic Acid }(\mathrm{g} / 100 \mathrm{~g} \\
\text { protein) }\end{array}$} & \multirow{2}{*}{$\begin{array}{l}\text { Thickness } \\
\qquad(\mu \mathrm{m})\end{array}$} & \multirow{2}{*}{$\begin{array}{l}\text { Moisture } \\
\text { content (\%) }\end{array}$} & \multicolumn{3}{|c|}{ Color parameters } & \multirow{2}{*}{ Gloss $\left(60^{\circ}\right)$} \\
\hline & & & $L^{*}$ & $a^{*}$ & $b^{*}$ & \\
\hline 0 & $91 \pm 7^{a}$ & $15.3 \pm 0.6^{a}$ & $19.7 \pm 2.1^{\mathrm{ab}}$ & $27.0 \pm 0.7^{a}$ & $31.0 \pm 3.5^{a}$ & $66.2 \pm 0.1^{\mathrm{a}}$ \\
\hline 1 & $98 \pm 18^{a}$ & $15.8 \pm 0.2^{\mathrm{a}}$ & $15.6 \pm 0.9^{b}$ & $24.4 \pm 1.5^{\mathrm{a}}$ & $21.5 \pm 1.7^{\mathrm{b}}$ & $63.6 \pm 1.8^{\mathrm{a}}$ \\
\hline 3 & $95 \pm 3^{a}$ & $15.3 \pm 0.7 a$ & $5.5 \pm 1.5^{c}$ & $13.6 \pm 3.5^{b}$ & $5.6 \pm 1.9^{c}$ & $68.3 \pm 2.5^{a}$ \\
\hline 6 & $93 \pm 1^{\mathrm{a}}$ & $15.7 \pm 0.1^{\mathrm{a}}$ & $1.5 \pm 0.6^{c}$ & $3.1 \pm 0.5^{c}$ & $0.8 \pm 0.4^{c}$ & $63.9 \pm 3.8^{a}$ \\
\hline 10 & $100 \pm 4^{a}$ & $13.3 \pm 0.4^{b}$ & $0.9 \pm 0.3^{c}$ & $1.7 \pm 0.9^{c}$ & $-0.3 \pm 0.2^{c}$ & $55.5 \pm 1.2^{\mathrm{b}}$ \\
\hline
\end{tabular}
acid.

Different letters on the same column indicate significantly different values $(p<0.05) .{ }^{1}$ on a wet basis.

The films conditioned at $53 \% \mathrm{RH}$ presented moisture values ranging from 13.3 to $15.8 \%$, which decreased $(p<0.05)$ with higher gallic acid concentrations $(10 \%)$, probably due to the hygroscopic effect of GA in high concentration. These moisture values (Table 1) were similar to those obtained in films from CBCP modified with tannic acid, glutaraldehyde, and glyoxal $[5,6]$

\section{Color, opacity and gloss}

The color of the CBCP films is an important characteristic for application in agriculture, specifically in the management of plant seedlings. These films should preferably have a dark color to avoid the incidence of light, preventing root weakening. The CBCP films without gallic acid presented a dark brown color, evidenced by the luminosity $\left(L^{*}=20\right)$, and chrome values $\left(a^{*}=27\right.$ and $\left.b^{*}=31\right)$ (Table 1). Similar results were observed for films produced with this protein modified with tannic acid, glutaraldehyde, and glyoxal $[5,6]$. The addition of gallic acid in the CBCP film formulation led to a decrease in the $L^{*}, a^{*}$, and $b^{*}$ parameters $(p<0.05)($ Table 
$1)$, as well as an exponential decrease in the total color difference values $\left(\Delta E^{*}\right)$, calculated in relation to the black standard (Figure 1). The decrease in $\Delta E^{*}$ values means that the color of the films is close to black, that is, the modification of the proteins by gallic acid has produced darker films. The addition of gallic acid led to the major color changes since this agent is not stable to high $\mathrm{pH}$ [24], thus oxidize yielding darkened films. Similar results were observed for films produced from chitosan; tannic acid addition changed the film color, resulting in brownish films [25].

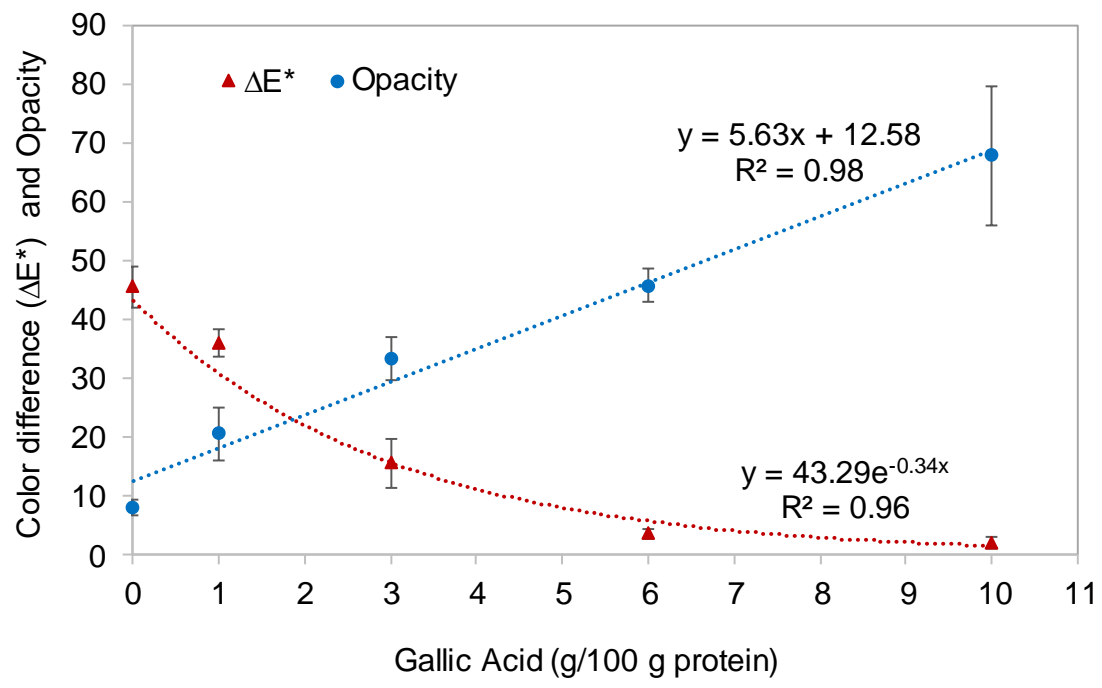

Figure 1. Color difference $\left(\Delta E^{\star}\right)$ and Opacity of films made with castor bean cake protein modified by gallic acid.

On the other hand, it was also observed that the CBCP film opacity increased linearly with increasing the gallic acid concentration in the formulation (Figure 1). Opaque films are also interesting for application in agriculture that requires protection from sunlight. Changes in color and film opacity as a function of protein modification by tannins were also observed in sunflower cake protein films [26].

The gloss of the CBCP films were not significantly $(p>0.05)$ affected by the addition of gallic acid at concentrations of 1,3 , and $6 \mathrm{~g} / 100 \mathrm{~g}$ protein, which remained around 65 , a value similar to that of the film without gallic acid (Table 1). A decrease $(p<0.05)$ in film gloss was observed with increasing acid concentration to $10 \mathrm{~g} / 100 \mathrm{~g}$, indicating an increase in film surface irregularities, thus affecting light reflectance. Castor protein-based films modified by gallic acid $(0-10 \mathrm{~g} / 100 \mathrm{~g}$ protein) present an intermediate gloss level [27]. The gloss values of these films were lower than those of glutaraldehyde and glyoxal modified castor bean protein films (gloss $60^{\circ}=88$ - 96) [6] and those of montmorillonite gelatin films (gloss $60^{\circ}=70-160$ ) [28].

\section{Film solubility}

The modification of CBCP by gallic acid $(1-6 \mathrm{~g} / 100 \mathrm{~g}$ protein) led to a reduction $(p<0.05)$ of the films solubility from 87 to $76 \%$ (Table 2). However, films prepared with proteins modified with $10 \mathrm{~g}$ of gallic acid/100 $\mathrm{g}$ were more soluble $(p<0.05)$ in water than those containing $1-6 \mathrm{~g}$ of gallic acid/100 $\mathrm{g}$ of protein. Increasing the percentage of gallic acid beyond the maximum amount that can be bound to the network would therefore load the film with additional gallic acid, damaging its coherence. Therefore, at concentrations above a certain limit, gallic acid make the films more soluble.

The relative high solubility of these films can be due to both the protein composition, with several polar amino acids with good affinity for water, such as aspartic acid and arginine present in high concentrations [6] and a large amount of glycerol $(30 \%)$ in the formulation. The solubility values obtained in this study were similar to those of glutaraldehyde modified castor cake protein (solubility $=65-76 \%$ ) but higher than those produced with glyoxal-modified proteins (solubility $=43-50 \%$ ) [6]. The difference in behavior between these protein modifiers may be due to the type of bond formed during modification of the proteins. In the case of glutaraldehyde and glyoxal, the chemical bonds are covalent, while in the particular case of gallic acid, which has three hydroxyl groups in the molecule, the bonds may be hydrogen with carboxyl groups of aspartic and glutamic acids present in high proportion in castor cake proteins [6] 
Table 2. Solubility in water and mechanical properties of films made with castor bean cake protein modified by gallic acid.

\begin{tabular}{ccccc}
\hline Gallic Acid (g/100 g protein) & $\begin{array}{c}\text { Solubility } \\
(\%)\end{array}$ & $\begin{array}{c}\text { Tensile } \\
\text { strength (MPa) }\end{array}$ & $\begin{array}{c}\text { Elongation at } \\
\text { break (\%) }\end{array}$ & $\begin{array}{c}\text { Elasticity modulus } \\
\text { (MPa/\%) }\end{array}$ \\
\hline 0 & $87.0 \pm 3.5^{\mathrm{ab}}$ & $2.8 \pm 0.4^{\mathrm{ab}}$ & $67.5 \pm 10.2^{\mathrm{a}}$ & $0.63 \pm 0.17^{\mathrm{ab}}$ \\
1 & $82.9 \pm 3.1^{\mathrm{bc}}$ & $2.2 \pm 0.1^{\mathrm{b}}$ & $81.9 \pm 4.2^{\mathrm{a}}$ & $0.45 \pm 0.05^{\mathrm{b}}$ \\
6 & $76.1 \pm 1.9^{\mathrm{d}}$ & $2.5 \pm 0.1^{\mathrm{ab}}$ & $91.1 \pm 6.2^{\mathrm{a}}$ & $0.55 \pm 0.04^{\mathrm{ab}}$ \\
10 & $76.7 \pm 2.8^{\mathrm{cd}}$ & $3.4 \pm 0.5^{\mathrm{a}}$ & $70.7 \pm 10.7^{\mathrm{a}}$ & $0.86 \pm 0.14^{\mathrm{a}}$ \\
\hline
\end{tabular}

Different letters on the same column indicate significantly different values $(p<0.05)$.

\section{Mechanical properties}

Variation in the concentration of gallic acid changed tensile strength and elasticity modulus of CBCP films, but elongation values were not changed significantly (Table 2). A high tensile strength was observed for film prepared with $6 \mathrm{~g}$ gallic acid $/ 100 \mathrm{~g}$ protein. These results showed that the new bonds formed strengthened the biopolymeric matrix. Similar results were observed in films of sunflower protein isolate modified by gallic acid [9]. These authors reported that in concentration of gallic acid above $2 \%$, the films had their resistance and flexibility diminished significantly. This demonstrates the importance of evaluating the effect of gallic acid concentration for each protein in particular. Gallic acid, in excess had not a plasticizer effect in the CBCP films, as observed in films made with zein and gluten [11,29].

Considering that the CBCP films produced with $6 \mathrm{~g}$ of gallic acid/100 g protein presented lower solubility, higher tensile strength, higher elasticity, lower opacity and dark color; they were chosen for the study of biodegradability in soil. For comparison purposes, films with proteins from castor-cake modified with tannic acid (carbon content of the films $=36.8 \%$ ) were also produced, whose preparation methodologies and properties are described by Chambi and coauthors [5], besides films prepared only with these proteins.

\section{Biodegradability}

The biodegradability of the films was determined by measuring the carbon dioxide released during the breakdown of the organic components of the castor protein films by natural microorganisms present in the soil in the presence of oxygen. All films exhibited an analogous degradation behavior, which can be represented in 3 steps (Figure 2). In the initial phase, the degradation rate of the films increased sharply, reaching $45-62 \%$ in the first 10 days of the test. The second phase lasted 60 days and was characterized by a lower degradation rate. During this phase, the biodegradation gradually increased until reaching 78 to 92 $\%$. Finally, a plateau phase was observed during the remaining 23 days of the test. At the end of the test (93 days), all available carbon in the films without tannins was depleted (100\% biodegradability), while the films prepared with tannic and gallic acids had a degradation rate of 88 and $89 \%$, respectively.

The films prepared with proteins modified with both gallic and tannic acid showed a decrease in the degradation rate when compared to the film without these acids (Figure 2). These results indicate that the increase in the number of intermolecular bonds, leading to the formation of protein-tannin complexes in the film matrix, delayed the biodegradation.

The biodegradation kinetics were satisfactorily represented $\left(R^{2} \geq 0.98\right)$ by logarithmic models (Table 3 ), from which it was possible to calculate the average degradation time $\left(t_{1 / 2}\right)$ of these materials. This time corresponds to the period (days) of degradation of $50 \%$ of the material. The films produced with castor bean cake proteins had $t_{1 / 2}$ between 8 and 13 days, similar to the degradation time of the cellulose films $\left(t_{1 / 2}=6\right.$ 10 days), and higher than the gluten films ( $\mathrm{t}_{1 / 2}=4$ days) [30]. However, the biodegradability of the cellulose and gluten films assessed by the $\mathrm{CO}_{2}$ release was determined in liquid medium (activated sludge from a wastewater treatment plant) rather than the medium (soil) used in the present study. The biodegradability of films based on poly (lactic acid) and its copolymers had $69-72 \%$ and $33-69 \%$ biodegradability, respectively, after 110 days [31]. 


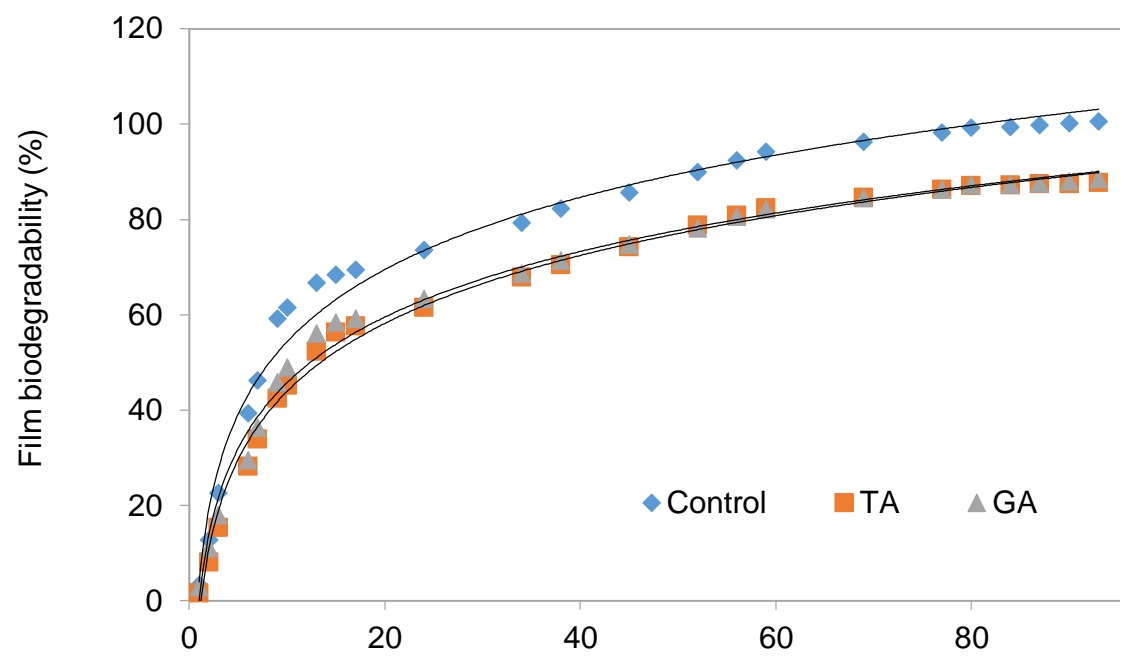

Figure 2. Biodegradability of films made with castor bean cake protein modified by gallic acid (GA) or tannic acid (TA). Control films were produced without addition of GA and TA. Points represent experimental data, and lines represent the results of fitting of equations in Table 3.

According to the biodegradability assessment standards [32], $60 \%$ of the carbon dioxide should be mineralized to $\mathrm{CO}_{2}$ within 45 days, so that the polymer can be called biodegradable. Thus, castor bean protein-based films with no addition of tannins and addition of gallic and tannic acids can be considered biodegradable, since $60 \%$ of the materials were mineralized, i.e. were biodegraded at 13, 21, and 22 days, respectively. These values were calculated using the equations in Table 3.

Table 3. Biodegradability (B) equations of films made with castor bean cake protein modified by gallic acid as a function of time $(\mathrm{t})$

\begin{tabular}{lccc}
\hline Films & Equations & $\mathbf{R}^{2}$ & $\mathbf{t}_{\mathbf{1 / 2}}$ (days) \\
\hline Control $^{1}$ & $\mathrm{~B}=21.87 \ln (\mathrm{t})+3.96$ & 0.98 & 8 \\
Gallic Acid $_{\text {Tannic Acid }}$ & $\mathrm{B}=19.86 \ln (\mathrm{t})+0.01$ & 0.99 & 12 \\
\hline
\end{tabular}

1 Without addition of gallic or tannic acid; $\mathrm{t} 1 / 2$, mean degradation time.

\section{CONCLUSION}

The CBCP film properties were affected by the gallic acid concentration: color parameters, gloss, solubility in water, tensile strength, elasticity and biodegradability. These effects can be due to an increase in the number of non-covalent bonds between adjacent peptides. The CBCP films were biodegraded in a slow manner than similar films without chemical modification.

Gallic acid influenced positively on the films color and opacity, producing films more dark and opaque in comparison with films without chemical modification. Due to these characteristics, these films can be interesting for application in agriculture, specifically in the management of plant seedlings. Moreover, films containing $6 \mathrm{~g}$ gallic acid/100 g protein presented better mechanical properties and low solubility in water than the other concentrations used in this work.

Funding: This research was funded by SÃO PAULO RESEARCH FOUNDATION (FAPESP), grant numbers 08/113415 and 09/10172-8.

Acknowledgments: The authors thank (1) the company "A. Azevedo Industria e Comércio de Óleos Ltda." (Itupeva, SP, Brazil) for donating the castor bean cake; (2) the Laboratory of Reuse (LABREUSO) of the Department of Sanitation and Environment (Faculty of Civil Engineering, UNICAMP, Brazil) for providing the infrastructure for biodegradability tests; (3) The Faculty of Animal Science and Food Engineering (University of São Paulo, USP, Brazil) for the infrastructure offered for the development of this research.

Conflicts of Interest: The authors declare no conflict of interest. The funders had no role in the design of the study; in the collection, analyses, or interpretation of data; in the writing of the manuscript, or in the decision to publish the results. 


\section{REFERENCES}

1. Coltelli M-B, Wild F, Bugnicourt E, et al. State of the Art in the Development and Properties of Protein-Based Films and Coatings and Their Applicability to Cellulose Based Products: An Extensive Review. Coatings. 2016;6(1):1-59.

2. Gómez-Estaca J, Gavara R, Catalá R, Hernández-Muñoz P. The potential of proteins for producing food packaging materials: a review. Packag Technol Sci. 2016;29:203-224.

3. Zink J, Wyrobnik T, Prinz T, Schmid M. Physical, chemical and biochemical modifications of protein-based films and coatings: An extensive review. Int J Mol Sci. 2016;17(9).

4. Burlein GAD, Rocha MCG. Mechanical and morphological properties of LDPE/ PHB blends filled with castor oil pressed cake. Mater Res. 2014;17(1):97-105.

5. Chambi HNM, Lacerda RS, Makishi GLA, Bittante AMQB, Gomide CA, Sobral PJA. Protein extracted from castor bean (Ricinus communis L.) cake in high pH results in films with improved physical properties. Ind Crops Prod. 2014;61:217-224.

6. Makishi GLA, Lacerda RS, Bittante AMQB, et al. Films based on castor bean (Ricinus communis L.) proteins crosslinked with glutaraldehyde and glyoxal. Ind Crops Prod. 2013;50:375-382.

7. Lacerda RS, Makishi GLA, Chambi HNM, et al. Castor Bean (Ricinus communis ) Cake Protein Extraction by Alkaline Solubilization: Definition of Process Parameters. Chem Eng Trans. 2014;37:775-780.

8. Oliveira TG, Makishi GLA, Chambi HNM, Bittante AMQB, Lourenço RV, Sobral PJ. Cellulose fiber reinforced biodegradable films based on proteins extracted from castor bean (Ricinus communis L.) cake. Ind Crops Prod. 2015;67:355-363.

9. Orliac O, Rouilly A, Silvestre F, Rigal L. Effects of additives on the mechanical properties, hydrophobicity and water uptake of thermo-moulded films produced from sunflower protein isolate. Polymer (Guildf). 2002;43:5417-5425.

10. Sun X, Wang Z, Kadouh H, Zhou K. The antimicrobial, mechanical, physical and structural properties of chitosangallic acid films. LWT - Food Sci Technol. 2014;57(1):83-89.

11. Arcan I, Yemenicioğlu A. Incorporating phenolic compounds opens a new perspective to use zein films as flexible bioactive packaging materials. Food Res Int. 2011;44(2):550-556.

12. Cheng S-Y, Wang B-J, Weng Y-M. Antioxidant and antimicrobial edible zein/chitosan composite films fabricated by incorporation of phenolic compounds and dicarboxylic acids. LWT - Food Sci Technol. 2015;63:115-121.

13. Battestin V, Matsuda LK, Macedo GA. Fontes e aplicações de taninos e tanases em alimentos. Aliment e Nutr. 2004;15(1):63-72.

14. Makishi GLA, Lacerda RS, Mamani HNC, et al. Effect of Alkaline Agent and pH on the Composition of FreezeDried Proteins Extracted from Castor Bean ( Ricinus communis L .) Cake. Chem Eng Trans. 2014;37:697-702.

15. Sobral PA, García FT, Habitante AMQB, Monterrey-Quintero ES. Propriedades de filmes comestíveis produzidos com diferentes concentrações de plastificantes e de proteínas do músculo de tilápia-do-nilo. Pesqui Agropecuária Bras. 2004;39(3):255-262.

16. ASTM D2457-13. Standard Test Method for Specular Gloss of Plastic Films and Solid Plastics. West Conshohocken, United States; 2013:1-6.

17. Villalobos R, Chanona J, Hernández P, Gutiérrez G, Chiralt A. Gloss and transparency of hydroxypropyl methylcellulose films containing surfactants as affected by their microstructure. Food Hydrocoll. 2005;19(1):53-61.

18. Gontard N, Guilbert S, Cuq J-L. Edible Wheat Gluten Films: Influence of the Main Process Variables on Film Properties using Response Surface Methodology. J Food Sci. 1992;57(1):190-195.

19. ASTM D882-95a. Standard Test Method for Tensile Properties of Thin Plastic Sheeting. New York, United States; 1995.

20. NBR 14283. Resíduos Em Solos - Determinação Da Biodegradação Pelo Método Respirométrico. Rio de Janeiro, Brasil.; 1999.

21. Rodella AA, Saboya LV. Calibration for conductimetric determination of carbon dioxide. Soil Biol Biochem. 1999;31(14):2059-2060.

22. ISO 17556. Determination of the Ultimate Aerobic Biodegradability of Plastic Materials in Soil by Measuring the Oxygen Demand in a Respirometer or the Amount of Carbon Dioxide Evolved. Geneva, Switzerland.; 2012.

23. Blick AP, Bonametti, Juliana Olivato Yamashita F, Souza JRP. Biodegradable bags for the production of plant seedlings. Polímeros. 2014;24(5):547-553.

24. Friedman $\mathrm{M}$, Jürgens $\mathrm{HS}$. Effect of $\mathrm{pH}$ on the stability of plant phenolic compounds. J Agric Food Chem. 2000;48(6):2101-2110.

25. Rivero S, García MA, Pinotti A. Crosslinking capacity of tannic acid in plasticized chitosan films. Carbohydr Polym. 2010;82(2):270-276.

26. Salgado PR, Molina Ortiz SE, Petruccelli S, Mauri AN. Biodegradable sunflower protein films naturally activated with antioxidant compounds. Food Hydrocoll. 2010;24(5):525-533. 
27. ASTM D523-14. Standard Test Method for Specular Gloss. West Conshohocken, United States; 2014:1-5.

28. Flaker CHC, Lourenço R V., Bittante AMQB, Sobral PJA. Gelatin-based nanocomposite films: A study on montmorillonite dispersion methods and concentration. J Food Eng. 2015;167:65-70.

29. Hager A-S, Vallons KJR, Arendt EK. Influence of gallic acid and tannic acid on the mechanical and barrier properties of wheat gluten films. J Agric Food Chem. 2012;60(24):6157-6163.

30. Domenek S, Feuilloley P, Gratraud J, Morel M-H, Guilbert S. Biodegradability of wheat gluten based bioplastics. Chemosphere. 2004;54(4):551-559.

31. Cadar O, Paul M, Roman C, Miclean M, Majdik C. Biodegradation behaviour of poly(lactic acid) and (lactic acidethylene glycol-malonic or succinic acid) copolymers under controlled composting conditions in a laboratory test system. Polym Degrad Stab. 2012;97(3):354-357.

32. ASTM D5338-15. Standard Test Method for Determining Aerobic Biodegradation of Plastic Materials Under Controlled Composting Conditions, Incorporating Thermophilic Temperatures. West Conshohocken, United States; 2015.

(C) 2020 by the authors. Submitted for possible open access publication under the terms and conditions of the Creative Commons Attribution (CC BY NC) license (https://creativecommons.org/licenses/by-nc/4.0/). 